\title{
Lactational responses to ruminally-protected methionine in cows fed a low-protein grass silage- based diet $^{*}$
}

\author{
P.M. Pisulewski' ${ }^{1}$ Z.M. Kowalski² and M. Görgülü ${ }^{3}$
}

\author{
The Agricultural University of Cracow. \\ 'Department of Human Nutrition, \\ ${ }^{2}$ Department of Animal Nutrition \\ al. 29 Listopada 46, 31-425 Krakow, Poland \\ ${ }^{3}$ Department of Animal Science, \\ University of Cukurova, Adana. Turkey
}

(Received 20 November 2001 ; accepted 9 May 2002)

\begin{abstract}
Twelve multiparous Polish Red-and-White cows, were assigned to two-factorial $(2 \times 2)$ arrangement of treatments, in a balanced changeover design, involving two levels of dietary protein (PDI: 100 vs $85 \%$ of the INRA requirement) and two levels of ruminally-protected DL-methionine (Smartami$n \mathrm{e}^{\mathrm{TM}} \mathrm{M}: 0 \mathrm{vs} 20 \mathrm{~g} / \mathrm{d}$ ). The cows were in wk $8-12$ of lactation and were fed a mixed diet with grass silage and concentrates representing 50 and $50 \%$ of the dietary DM, respectively. The four combinations of treatments were: $100 \%$ PDI $(0 \mathrm{~g} \mathrm{Met}), 100 \%$ PDI $(+20 \mathrm{~g} \mathrm{Met}), 85 \%$ PDI $(0 \mathrm{~g} \mathrm{Met})$ and $85 \%$ PDI ( 20 g Met). The calculated intestinal concentrations of lysine and methionine (\% PDI) were: 6.91 and $1.79,6.88$ and $2.27,6.88$ and $1.87,6.84$ and 2.42, respectively. Dry matter and net energy (UFL) intakes were similar across the treatments. Crude protein, PDIN and PDIE intakes were significantly $(\mathrm{P}<0.001$ ) higher in cows fed the $100 \%$ PDI dicts, as compared to those fed the $85 \%$ PDI diets. Milk and $4 \%$ FCM yields and the efficiency of milk production were not significantly different. Milk fat, lactose, and SNF contents did not respond to the treatments. Feeding the $100 \%$ PDI diets compared to the $85 \%$ PDI ones increased significantly $(\mathrm{P}<0.05$ ) milk protein yicld (from 0.67 to $0.76 \mathrm{~kg} / \mathrm{d}$ ). Milk NPN and urea concentrations were significantly $(\mathrm{P}<0.001)$ decreased, and the relative concentration of milk protein $\mathrm{N}(\%$ of total $\mathrm{N})$ was significantly $(\mathrm{P}<0.05)$ increased in milk from cows fed the $85 \%$ PDl diets compared to the $100 \%$ PDI diets. No effects of methionine supplementation and no interactions between dietary protein intakes and supplemental methionine levels on the variables
\end{abstract}

* Supported by the State Committee for Scientific Research, Grant No P06E 01010 and P06E 00215 
addressed in this study were detected. It is concluded that supplementing ruminally-protected methionine to grass silage-based diets did not result in any apparent changes in lactational responses, regardless of the protein status of these cows, thus indicating that methionine is not the first limiting amino acid in these diets.

KEY WORDS: dairy cow, grass silage, protein level, protected methionine, milk yield, milk composition

\section{INTRODUCTION}

The use of nutritional strategies to improve the composition and quality of food products of animal origin (e.g. milk) is a relatively new approach that has emerged at the interface of animal science, food science and human nutrition. In this context, increasing milk protein yield and content, has received particular attention. Generally, two major approaches, i.e. genetic and nutritional (Kenelly and Glimm, 1998), are currently applied to alter milk composition. However, genetic methods are not capable of responding to short-term changes in human consumption patterns of milk components. On the other hand, nutritional manipulation of milk composition brings immediate changes in the amounts of milk components, including milk protein (Murphy and O'Mara, 1993). Several major nutritional strategies are currently available, including: increasing dietary energy and protein intake and feeding protected amino acids, at least L-lysine and DL-methionine, to dairy cows. The latter has been shown to be the most effective means of maximising milk protein yield and content (Rulquin, 1992; Schwab, 1995) and minimising the amount of excess $\mathrm{N}$ that the cow must excrete (Dinn et al., 1998). These beneficial effects, resulting mainly from the optimisation of amino acid profile available for absorption in the small intestine, were demonstrated both in dairy cows fed maize silage-based diets, and to a lesser extent in dairy cows offered grass silage-based diets (Sloan, 1997; Xu et al., 1998; Younge et al., 2001).

Since increasing dietary protein intake leads inevitably to increased nitrogen excretion and has a negative environmental impact, the subject of the present studies was to determine milk protein responses of dairy cows fed standard grass silage-based diets $(\sim 18$ vs $\sim 14 \% \mathrm{CP})$, formulated to supply adequate or inadequate amounts of protein digestible in the small intestine (PDI); equivalent of $\sim 100$ and $\sim 85 \%$ of the INRA (1989) recommended amounts. In addition, we examined the hypothesis that balancing postruminal amino acid supply with protected DL-methionine, would allow for the reduction of dietary protein (PDI) intake, below the recommended level, without adversely affecting milk protein responses of the cows. 


\section{MATERIAL AND METHODS}

\section{Cows and management}

Twelve multiparous Red-and White cows (body weight $600 \pm 30 \mathrm{~kg}$ ), in their second or third lactation, were randomly assigned to the experiment, 8-12 weeks post-calving. Their average pre-experimental milk yields were $25 \pm 4 \mathrm{~kg} / \mathrm{d}$. The animals were fed and milked twice daily at 05.30 and 06.00 and 17.30 and 18.00 , respectively. They were fed and housed individually in the tie-stall barn.

\section{Design and treatments}

A two-factorial $(2 \times 2)$ experiment, involving twelve cows fed two levels of dietary protein (adequate vs inadequate) and two levels of ruminally-protected DL-methionine (Smartamine ${ }^{\mathrm{TM} M}$ ), was arranged as a balanced two-period changeover design (Gill and Magee, 1976), with two 21-d experimental periods. It was based on six Latin squares of size 2 . In each square one treatment was followed by one of the three remaining treatments. As a result 12 animals were required when two animals were used in each Latin square. Consequently, there were six replications of each treatment. This kind of completely balanced design limits the possible carry-over effects.

\section{Diets and feeding}

The basal experimental diets (Table 1) consisted of wilted grass silage $(50 \%$ $\mathrm{DM})$ and concentrates (50\% DM). They were formulated and fed to provide $100 \%$ of net lactational energy (UFL; $1 \mathrm{UFL}=1700 \mathrm{kcal} \mathrm{NE}$ ). At the same time, they were designed either to provide adequate $(\sim 100 \%$ PDI $)$ or inadequate $(\sim 85 \%$ PDI $)$ amount of protein to the cows, as protein truly digested in the small intestine (PDI), required for maintenance and lactation according to the INRA (1989) recommendations. In addition, the cows were given two levels of ruminally-protected DL-methionine (Smartamine ${ }^{\mathrm{TM}} \mathrm{M}: 0$ vs $20 \mathrm{~g} / \mathrm{d}$ ). Smartamine ${ }^{\mathrm{TM}} \mathrm{M}(70 \%$ DL-methionine) was a commercial product obtained from Rhône-Poulenc Animal Nutrition (Poland). The amino acid supplement was mixed with a small amount of wheat bran, then top-dressed, and fed to cows according to the design.

Concentrations of UFL and PDI were based on the tabulated values of the INRA (1989) system, whereas lysine and methionine in the sum of total AA passing to the small intestine (i.e. PDI) were calculated using an amino acid profiling method described elsewhere (Rulquin et al., 1998).

The diet was offered in two equal parts. Water and mineralized salt licks were available daily. 
Ingredients, nutrient contents (\% DM $\left.{ }^{1}\right)$ and nutritive value of experimental diets

\begin{tabular}{|c|c|c|}
\hline Specification & $\begin{array}{l}\text { Adequate diet } \\
(\sim 100 \% \text { PDI })\end{array}$ & $\begin{array}{l}\text { Inadequate diet } \\
\text { ( } \sim 85 \% \text { PDI })\end{array}$ \\
\hline \multicolumn{3}{|l|}{ Ingredients } \\
\hline grass silage & 50 & 50 \\
\hline concentrate & $50^{2}$ & $50^{3}$ \\
\hline \multicolumn{3}{|l|}{ Chemical composition } \\
\hline dry matter, $\%$ of fresh matter & 33.1 & 33.0 \\
\hline organic matter & 91.0 & 91.4 \\
\hline crude protein & 17.7 & 14.4 \\
\hline ether extract & 4.6 & 4.8 \\
\hline crude fibre & 17.8 & 17.5 \\
\hline NDF & 40.0 & 40.9 \\
\hline $\mathrm{ADF}$ & 26.5 & 26.1 \\
\hline $\mathrm{Ca}$ & 0.60 & 0.58 \\
\hline $\mathrm{P}$ & 0.51 & 0.50 \\
\hline \multicolumn{3}{|l|}{ Nutritive value } \\
\hline $\mathrm{UFL}^{4} / \mathrm{kg} \mathrm{DM}$ & 0.97 & 0.97 \\
\hline PDI $(E)^{5}, \mathrm{~g} / \mathrm{kg}$ DM & 99 & 86 \\
\hline PDI $(N)^{5}, g / k g ~ D M$ & 113 & 89 \\
\hline LysDI $\% \mathrm{PDI}^{6}$ & 6.91 & 6.88 \\
\hline $\mathrm{MelDI} \% \mathrm{PDI}^{\mathrm{s}}$ & 1.79 & 1.87 \\
\hline
\end{tabular}

1 diets were supplemented $(100 \mathrm{~g} / \mathrm{cow} / \mathrm{d})$ with a commercial mineral-vitamin mixture „Kuh-Gold2000 " (Polskie Sano, Poland)

2 contained (\% DM): ground barley - 70, soyabean meal - 25, wheat bran - 1, sodium bicarbonate - 2, dicalcium phosphate - $1, \mathrm{NaCl}-1$

3 contained (\% DM): ground barlcy - 92, soyabean meal - 3, wheat bran - 1, sodium bicarbonatc - 2, dicalcium phosphate - 1 , and sodium chioride - 1

${ }^{4} 1 \mathrm{UFL}=1700 \mathrm{kcal} \mathrm{NE}$ (INRA, 1989)

5 protein truly digested in the small intestine. The PDI(E) was calculated from the amount of energy and the PDI(N) from the amount of $\mathrm{N}$ available in the rumen for microbial protein synthesis (INRA, 1989)

${ }^{6}$ absorbable Lys and Met, \% of PDI

\section{Measurements, sample collection, and preparation}

For the third week of each 21-d experimental period, the amounts of feed offered and refused were recorded daily, and their representative samples were taken for determination of DM in a forced-air oven at $80^{\circ} \mathrm{C}$ for $48 \mathrm{~h}$. They were composited to form weekly samples for each cow for further analyses. Milk yields 
were recorded daily at each milking, and milk samples taken during the $5 \mathrm{~d}$ periods indicated above were assayed for protein, fat and lactose content, by infrared analysis, using a Milkoscan 133B (Foss Electric, Denmark). Moreover, on $\mathrm{d} 3$ of the sampling period samples from a.m. and p.m. milkings were composited according to yield and analysed for $\mathrm{N}$ fractions.

\section{Analytical procedures}

Gross composition of feeds offered and refused was determined on dried $\left(100^{\circ} \mathrm{C}\right.$, $24 \mathrm{~h}$ ) and ground (Cyclotec ${ }^{\mathrm{TM}}$; Tecator, Sweden) samples, according to the standard AOAC procedures (1995). NDF and ADF were analysed using the methods of Goering and Van Soest (1970).

Milk total N, NPN, and noncasein N were determined as described by Hurtaud et al. (1993). Casein $\mathrm{N}$ was calculated as the difference between total $\mathrm{N}$ and noncasein $\mathrm{N}$, and true protein $\mathrm{N}$ as the difference between total $\mathrm{N}$ and $\mathrm{NPN}$. Urea in milk was determined according to Roseler et al. (1993), using a colorimetric diacetyl monoxime procedure (Sigma Diagnostics, No 535; Sigma-Aldrich, Poland).

\section{Statistical analysis}

The data obtained were analysed by ANOVA for a balanced two-period changeover design (Gill and Magee, 1976), using the general linear models procedure of SAS (1985). The model employed for statistical analysis was as follows:

$$
\mathrm{Y}_{\mathrm{ijk}}=\mu+\mathrm{C}_{\mathrm{i}}+\mathrm{P}_{\mathrm{j}}+\mathrm{T}_{\mathrm{k}}+\mathrm{E}_{\mathrm{ijk}} \text {, }
$$

where: $\mu=$ general mean, $C_{i}=$ cow effect, $P_{j}=$ period effect, $T_{k}=$ treatment effect, and $\mathrm{E}_{\mathrm{ijk}}=$ experimental error. All data are expressed and presented throughout the text as least square means. Differences were considered to be significant at $\mathrm{P}<0.05$, unless otherwise indicated.

\section{RESULTS}

The dry matter intake averaged $15.2 \mathrm{~kg}$ (Table 2) and was not significantly different across the treatments. As derived from calculations based on dry matter intake and $4 \% \mathrm{FCM}$ yield, the experimental diets did not fully meet energy $\left(\mathrm{NE}_{\mathrm{L}}\right)$ requirements of the cows. Nonetheless, at the average energy supply of $15.5 \mathrm{UFL}$, the average energy deficit was 1.5 UFL and differences between treatments were insignificant. Derived as above, the actual amounts of PDI supplied by the experimental diets covered 102.0 and $87.5 \%$ of the INRA (1989) recommended PDI requirement. The restriction of dietary protein was apparently reflected by highly 


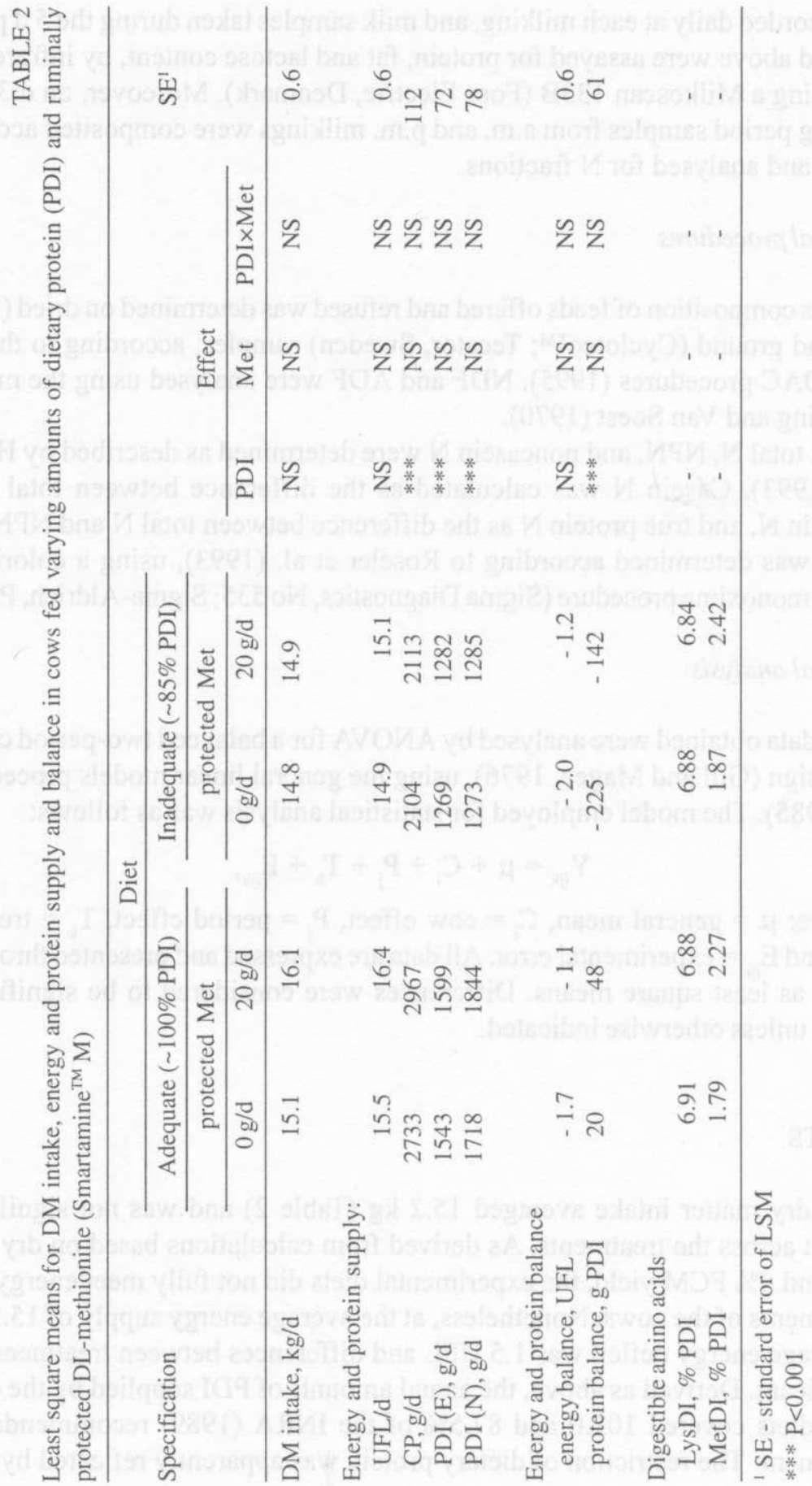


significant $(\mathrm{P}<0.001)$ differences in total protein, $\mathrm{PDIE}$ and PDIN intakes between the cows fed the adequate $(\sim 100 \% \mathrm{PDI})$ and the inadequate $(\sim 85 \% \mathrm{PDI})$ amount of dietary protein. Consequently, highly significant $(\mathrm{P}<0.001)$ differences in the PDI balance (PDI intake - PDI requirement; see INRA, 1989 for details) between these cows were observed. For the former cows the average PDI balance was $+34 \mathrm{~g} / \mathrm{d}$ and for the latter the PDI balance was negative, averaging $-183 \mathrm{~g} / \mathrm{d}$. Available lysine concentrations (LysDI \% PDI), derived using amino acid profiling method (Rulquin et al., 1998), were similar among the treatments, whereas those of available methionine (MetDI \% PDI) were increased in diets supplemented with ruminally protected methionine (Smartamine ${ }^{\mathrm{TM}} \mathrm{M} ; 20 \mathrm{~g} / \mathrm{d}$ ), as planned.

Generally, no apparent lactational responses of dairy cows to dietary treatments were found (Table 3). Average milk yield, 4\% FCM yield and the efficiency of milk production were not significantly affected. Nevertheless, the milk and 4\% FCM yield tended to be increased in the cows fed high-protein vs low-protein diets (averaging $24.5 \mathrm{vs} 23.1 \mathrm{~kg} / \mathrm{d}$ and $23.2 \mathrm{vs} 21.7 \mathrm{~kg} / \mathrm{d}$, respectively). Milk fat, lactose, and SNF content and their yield in milk did not respond to the treatments. At the same time, feeding restricted amounts of protein $(\sim 85 \% \mathrm{PDI})$, causing the negative PDI balance, resulted in a significantly $(\mathrm{P}<0.05)$ decreased average milk protein yield $(0.76 \mathrm{vs} 0.67 \mathrm{~kg} / \mathrm{d})$. There were no significant effects of protected methionine (Smartamine $^{\mathrm{TM}} \mathrm{M} ; 20 \mathrm{~g} / \mathrm{d}$ ) on lactational responses of the cows.

Feeding restricted amounts of dietary protein resulted in significant changes in milk nitrogen $(\mathrm{N})$ fractions (Table 4). Highly significant $(\mathrm{P}<0.001)$ decreases in non-protein $\mathrm{N}$ and urea $\mathrm{N}$ fractions were apparent. Consequently, the above changes led to significant $(\mathrm{P}<0.05)$ increases in the relative concentration of protein $\mathrm{N}$ expressed in total $\mathrm{N}$. At the same time, milk $\mathrm{N}$ fractions did not respond significantly to methionine supplementation.

The interactions between dietary protein (PDI) intakes and supplemental ruminally-protected methionine levels on the studied variables were insignificant.

\section{DISCUSSION}

The objective of the present study was to describe the productive responses in lactating dairy cows fed grass silage based-diets. The diets were formulated to provide adequate or inadequate amounts of protein digestible in the small intestine (PDI: $\sim 100$ vs $\sim 85 \%$ of INRA recommendations), without or with ruminally-protected DL-metionine supplementation (Smartamine ${ }^{\mathrm{TM}} \mathrm{M}: 0 \mathrm{vs} 20 \mathrm{~g} / \mathrm{d}$ ). Since no interactions between the levels of dictary protein intake and supplemental ruminally-protected DL-methionine were detected, only effects of main treatments will be discussed.

Generally, dry matter and net energy (UFL) intakes were comparable and unaffected significantly by the treatments (Table 2). However, these variables 


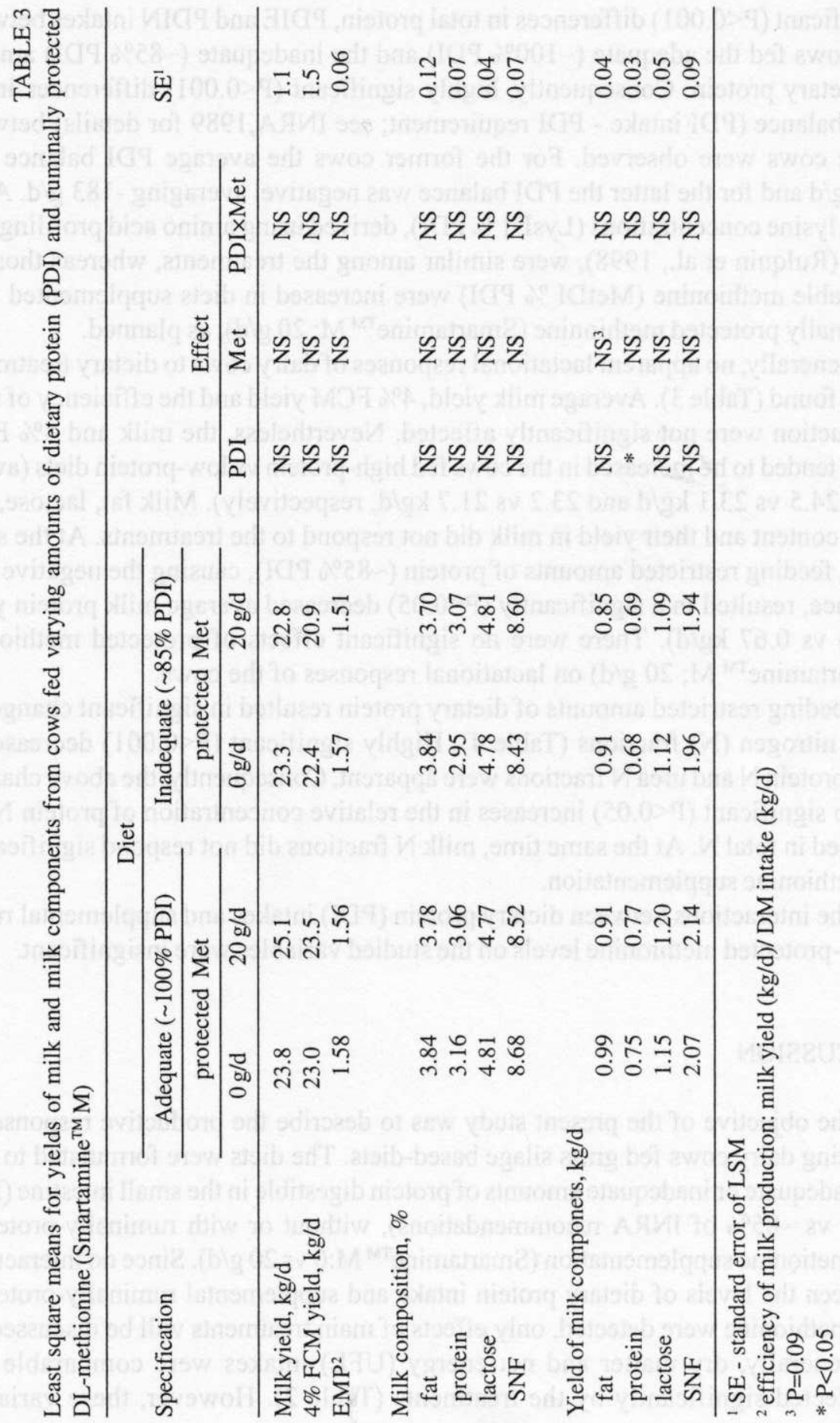




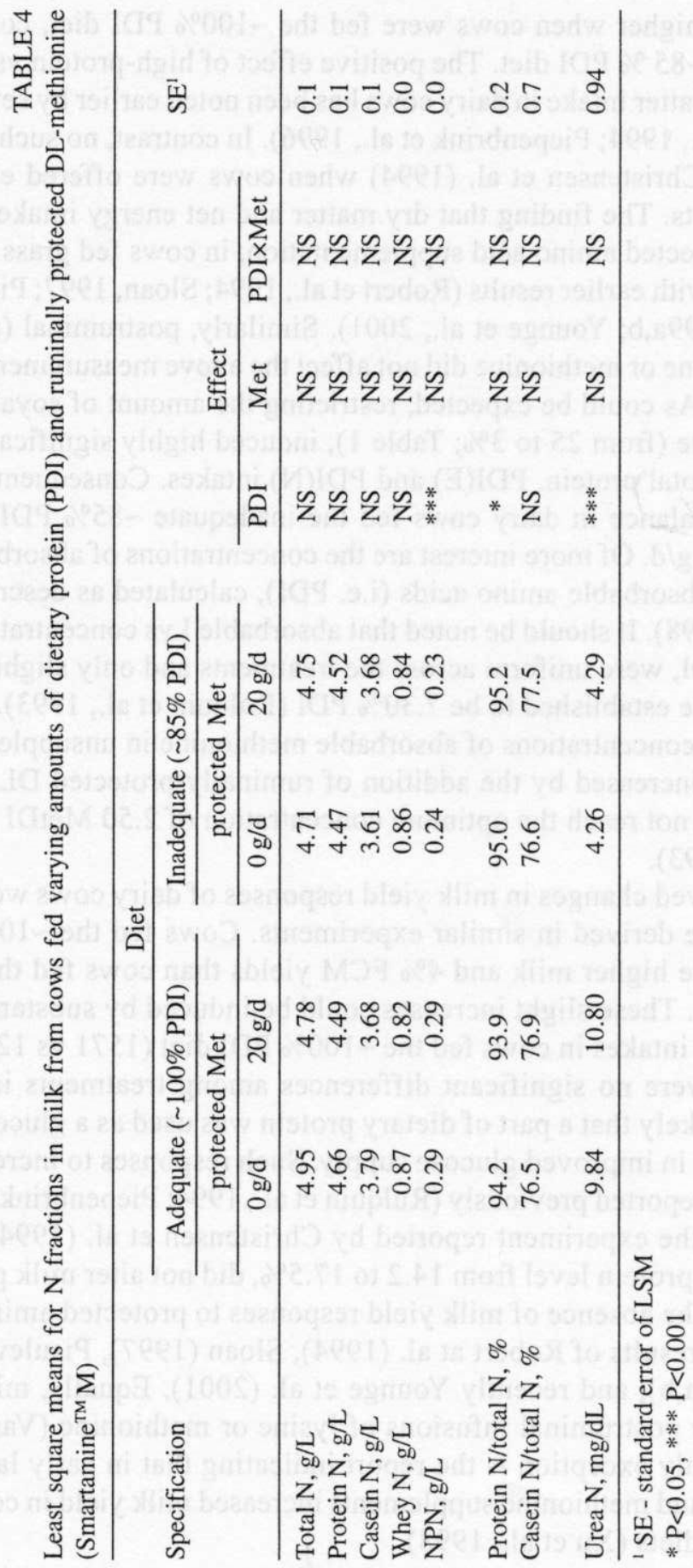


tended to be higher when cows were fed the $\sim 100 \%$ PDI diet, compared with cows fed the $\sim 85 \%$ PDI diet. The positive effect of high-protein vs low-protein diets on dry matter intake in dairy cows has been noted earlier by several authors (Rulquin et al., 1994; Piepenbrink et al., 1996). In contrast, no such effects were observed by Christensen et al. (1994) when cows were offered either 17.5 or $14.2 \% \mathrm{CP}$ diets. The finding that dry matter and net energy intakes were unaffected by protected amino acid supplementation, in cows fed grass silage-based diets, agrees with earlier results (Robert et al., 1994; Sloan, 1997; Pisulewski and Kowalski, 1999a,b; Younge et al., 2001). Similarly, postruminal (abomasal) in fusions of lysine or methionine did not affect the above measurements (Varvikko et al., 1999). As could be expected, restricting the amount of soyabean meal in the concentrate (from 25 to $3 \%$; Table 1), induced highly significant $(\mathrm{P}<0.001)$ decreases in total protein, $\mathrm{PDI}(\mathrm{E})$ and $\mathrm{PDI}(\mathrm{N})$ intakes. Consequently, the negative protein balance in dairy cows fed the inadequate $\sim 85 \%$ PDI diet was on average $-183 \mathrm{~g} / \mathrm{d}$. Of more interest are the concentrations of absorbable Lys and Met in total absorbable amino acids (i.e. PDI), calculated as described by Rulquin et al. (1998). It should be noted that absorbable Lys concentrations, averaging $6.88 \%$ PDI, were uniform across the treatments and only slightly below the optimum value established to be $7.30 \%$ PDI (Rulquin et al., 1993). At the same time, the low concentrations of absorbable methionine in unsupplemented diets were largely increased by the addition of ruminally-protected DL-methionine. Still, they did not reach the optimum concentration of 2.50 MetDI \% PDI (Rulquin et al., 1993).

The observed changes in milk yield responses of dairy cows were comparable with those derived in similar experiments. Cows fed the $\sim 100 \%$ PDI diet tended to have higher milk and 4\% FCM yields than cows fed the $\sim 85 \%$ PDI diet (Table 3 ). These slight increases could be induced by substantially higher protein (PDI) intakes in cows fed the $\sim 100 \%$ PDI diet (1571 vs $1275 \mathrm{~g} \mathrm{PDI} / \mathrm{d}$ ). Since there were no significant differences among treatments in the energy supply, it is likely that a part of dietary protein was used as a glucose precursor thus resulting in improved glucose supply. Such responses to increased protein intakes were reported previously (Rulquin et al., 1994; Piepenbrink et al., 1996). However, in the experiment reported by Christensen et al. (1994), increasing dietary crude protein level from 14.2 to $17.5 \%$, did not alter milk production in dairy cows. The absence of milk yield responses to protected amino acids is in line with the results of Robert at al. (1994), Sloan (1997), Pisulewski and Kowalski (1999a,b), and recently Younge et al. (2001). Equally, milk yield was unaffected by postruminal infusions of lysine or methionine (Varvikko et al., 1999). The only exception is the report indicating that in early lactation, protected lysine and methionine supplements increased milk yield in cows fed grass silage-based diets (Xu et al., 1998). 
The absence of any significant changes in milk composition was unexpected (Table 3). In comparable cxperiments, except that of Christensen et al. (1994), increasing dietary protein produced significant increases in milk protein content (Rulquin, 1992; Rulquin et al., 1994; Piepenbrink et al., 1996). The same was true for feeding protected amino acids (lysine, methionine or both) (Rulquin, 1992; Rulquin et al., 1994; Robert et al., 1994; Chillard et al., 1995; Piepenbrink et al., 1996; Xu et al., 1998; Younge et al., 2001). However, in some trials, milk protein concentration responses to protected methionine as the only supplemental amino acid were less convincing (Pisulewski and Kowalski, 1999b; Younge et al., 2001). These inconsistent results may be explained in terms of the insufficient supply of the colimiting lysine. Indeed, in studies using diets where lysine supply was adequate, methionine alone gave significantly higher milk protein concentration (Robert et al., 1994; Chilliard et al., 1995; Pisulewski et al., 1996). At the same time, neither lysine nor methionine were limiting for milk protein concentration in cows offered a grass silage-based diet (Varvikko et al., 1999). Significant $(\mathrm{P}<0.05)$ increases in milk protein yield, in cows fed the $\sim 100 \%$ PDI diet, resulted only from the apparent trend for increased milk yield (Table 3). In other studies, increasing dietary protein resulted in both, increased milk yield and milk protein content (Rulquin, 1992; Rulquin et al., 1994; Piepenbrink et al., 1996). In contrast to our findings (Table 3), feeding ruminally-protected lysine, methionine or both (associated with increased milk protein content) brings usually improvements in milk protein yicld (Rulquin, 1992; Robert et al., 1994; Rulquin et al., 1994; Chillard et al., 1995; Pisulewski et al., 1996). As could be expected (see above), this effect was not observed by Varvikko et al. (1999).

The detected changes in milk $\mathrm{N}$ fractions (Table 4) were clearly indicative of inadequate dietary protein (PDI) supply at the $\sim 85 \%$ PDI level. Highly significant $(\mathrm{P}<0.001)$ reduction in NPN and urea concentrations and significantly $(\mathrm{P}<0.05)$ increased protein $\mathrm{N}$ : total $\mathrm{N}$ ratio in milk of cows fed the $\sim 85 \% \mathrm{PDI}$ diet were anticipated as resulting from restricted protein supply. Moreover, in contrast to the $100 \%$ PDI diet, the $\sim 85 \%$ PDI diet did not supply an excess of PDIN (Table 2). The parallel decreases in milk NPN and urea fractions reflected the role of urea as the major component of NPN in milk (dePeters and Cant, 1992). Similar decreases in milk NPN and increased protein N: total N ratio in milk, in cows fed low-protein vs high-protein diets were also observed by Christensen et al. (1994). In contrast, in studies of Piepenbrink et al. (1996), decreasing dietary crude protein level from 18 to $14 \%$ did not affect milk NPN nor protein $\mathrm{N}$ : total $\mathrm{N}$ ratio in milk. The absence of responses to ruminally-protected methionine (Table 4) was unexpected. Feeding ruminally-protected lysine and methionine to cows resulted usually in increased true protein and casein fractions in milk and was a common feature of several studies (Rulquin, 1992; Christensen et al., 1994; Robert et al., 1994; Piepenbrink et al., 1996; Xu et al., 1998; Younge et al., 2001). 
Nonetheless, the above effects were not demonstrated in cows fed grass silage and cereal concentrate diets (Pisulewski and Kowalski, 1999a,b). Likewise, neither lysine nor methionine increased casein fraction in milk of cows fed a grass silage-based diet (Varvikko et al., 1999).

Overall, the protein status of the experimental cows fed either the $\sim 100$ or $\sim 85 \%$ PDI diets was induced to be apparently different. At the same time, the different PDI supply had no effect on the majority of lactational responses of the animals. The only exception was a significant decrease $(P<0.05)$ in milk protein yield in cows fed the $\sim 85 \%$ PDI diet. However, the above results do not invalidate the INRA (1989) PDI standards. Namely, the lack of significant decreases in the majority of lactational responses, when the cows were fed the $\sim 85 \%$ PDI diet, could have resulted from the utilization of body reserves of amino acids; the feature of short-term experiments. Hence, more probably, apparent decreases in lactational responses could have been seen in cows fed the $\sim 85 \%$ PDI diet, in a long-term trial.

At the same time no responses to postruminal supplementation of either diet with ruminally-protected DL-methionine (Smartamine ${ }^{\mathrm{TM}} \mathrm{M}: 0 \mathrm{vs} 20 \mathrm{~g} / \mathrm{d}$ ) were detected. Therefore, it seems likely that other amino acids or nutrients might have been limiting, or colimiting, for synthesis of milk or milk protein. Indeed, a recent experiment, using dairy cows fed grass silage-based diets, and infused abomasally with graded doses of histidine, lysine and methionine clearly indicated that histidine was the first limiting amino acid for these cows (Vanhatalo et al., 1999). Furthermore, neither lysine nor methionine was found to be the second limiting amino acids in the above studies.

\section{CONCLUSIONS}

Supplementing ruminally-protected methionine to grass silage-based diets did not result in any apparent changes in lactational responses, regardless of the protein status ( $100 \mathrm{vs} \sim 85 \%$ PDI requirement) of the cows. The lack of decrease in lactational responses when the cows were fed the $\sim 85 \%$ PDI diet could have resulted from the utilization of body reserves of amino acids in this short-term experiment.

\section{ACKNOWLEDGEMENTS}

The authors wish to thank Mrs. Alina Marszałek for chemical analyses and the staff of the dairy farm at the Lipowa Experimental Station (Research Institute of Animal Production, Poland) for the care and feeding of cows. 


\section{REFERENCES}

AOAC, 1995. Association of Official Analytical Chemists, Official Methods of Analysis. 16th Edition. Arlington, VA

Chillard Y., Rouel J., Ollier A., Bony J., Tanan K., Sloan B.K., 1995. Limitations in digestible methionine in the intestine (MetDI) for milk protein secretion in dairy cows fed a ration based on grass silage. Anim. Sci. 60, 553 (Abstr.)

Christensen R.A., Cameron M.R., Clark J.H., Drackley J.K., 1994. Effects of amount of protein and ruminally protected amino acids in the diet of dairy cows fed supplemental fat. J. Dairy Sci. 77 , 1619-1629

DePeters E.J., Can1 J.P., 1992. Nutritional factors influencing the nitrogen composition of bovine milk: a review. J. Dairy Sci. 75, 2044-2069

Dinn N.E., Shelford J.A., Fisher L.J., 1998. Use of the Net Carbohydrate and Protein System and rumen-protected lysine and methionine to reduce nitrogen excretion from lactating dairy cows. J. Dairy Sci. 81, 229-237

Gill J.L., Magee W.T., 1976. Balanced two-period change-over designs for several treatments. J. Anim. Sci. 42, 775-777

Goering H.K., Van Soest P.J., 1970. Forage Fiber Analyses (Apparatus, Reagents, Procedures, and Some Applications). Agriculture Handbook No. 379. ARS-USDA. Washington, DC

Hurtaud C., Rulquin H., Vérité R., 1993. Effect of infused volatile fatty acids and cascinate on milk composition and coagulation in dairy cows. J. Dairy Sci. 76, 3011-3020

INRA, 1989. R. Jarrige (Editor). Ruminant Nutrition: Recommended Allowances and Feed Tables. John Libbey Eurotext, London, pp. 289

Kennelly J.J., Glimm D.R., 1998. The biological potential to alter the composition of milk. Can. J. Anim. Sci. 78, Suppl., 23-56

Murphy J.J., O'Mara F., 1993. Nutritional manipulation of milk protein concentration and its impact on the dairy industry. Livest. Prod. Sci. 35, 117-134

Piepenbrink M.S., Overton T.R., Clark J.H., 1996. Response of cows fed a low crude protein diet to ruminally protected methionine and lysine. J. Dairy Sci. 79, 1638-1646

Pisulewski P.M., Kowalski Z.M., 1999a. The effect of protected lysine and methionine on milk yield and its composition in lactating dairy cows fed grass silage-based diets. J. Anim. Feed Sci. 8, 341 353

Pisulewski P.M., Kowalski Z.M., 1999b. The effect of protected methionine on milk yield and its composition in lactating dairy cows fed grass silage-based diets. J. Anim. Feed Sci. 8, 355-366

Pisulewski P.M., Rulquin H., Peyraud J.L., Vérité R., 1996. Lactational and systemic responses of dairy cows to postruminal infusions of increasing amounts of methionine. J. Dairy Sci. 79, 17811791

Robert J.C., Sloan B.K., Denis C., 1994. The effect of protected amino acid supplementation on the performance of dairy cows receiving grass silage plus soya-bean meal. Anim. Prod. 58, 437 (Abstr.)

Roseler D.K., Ferguson J.D., Sniffen C.J., Herrema J., 1993. Dietary protein degradability effects on plasma and milk urea nitrogen and milk nonprotein nitrogen in Holstein cows. J. Dairy Sci. 76, 525-534

Rulquin H., 1992. Intérets et limites d'un apport de méthionine et de lysine dans l'alimentation des vaches laitières. INRA Prod. Anim. 5, 29-36

Rulquin H., Pisulewski P.M., Vérité R., Guinard J., 1993. Milk production and composition as a function of postruminal lysine and methionine supply: a nutrient-response approach. Livest. Prod. Sci. 37, 69-90 
Rulquin H., Hurtaud C., Delaby L., 1994. Effects of dietary protein level on lactational responses of dairy cows to rumen-protected methionine and lysine. Ann. Zootech. 43, 245 (Abstr.)

Rulquin H., Guinard J, Vérité R., 1998. Variation of amino acid content in the small intestine digesta: development of a prediction model. Livest. Prod. Sci. 53, 1-13

SAS Institute Inc., 1985. SAS/STAT ${ }^{\mathrm{TM}}$. Guide for Personal Computers, Version 6. Carry, NC: SAS Institute, Inc.

Schwab C.G., 1995. Rumen-protected amino acids - their role in nutrition of high- producing ruminants. In: M. Ivan (Editor). Animal Science Research and Development: Moving Toward a New Century. Symposium on Challenges in Meeting Requirements of Modern Ruminants. Ottawa, pp. $161-175$

Sloan B.K., 1997. Developments in amino acid nutrition of dairy cows. In: P.C. Garnsworthy, J. Wiseman (Editors). Recent Advances in Animal Nutrition. Nottingham University Press, Nottingham, pp. 167-198

Vanhatalo A., Huhtanen P., Toivonen V., Varvikko T., 1999. Response of dairy cows fed grass silage diets to abomasal infusions of histidine alone or in combinations with methionine and lysine. J. Dairy Sci. 82, 2674-2685

Varvikko T., Vanhatalo A., Jalava T., Huhtanen P., 1999. Lactation and metabolic responses to graded abomasal doses of methionine and lysine in cows fed grass silage diets. J. Dairy Sci. 82, 26592673

Xu S., Harrison J.H., Chalupa W., Sniffen C., Julien W., Sato H., Fujieda T., Watanabe K., Ueda T., Suzuki H., 1998. The effect of ruminal bypass lysine and methionine on milk yield and composition of lactating cows. J. Dairy Sci. 81, 1062-1077

Younge B.A., Murphy J.J., Rath M., Stoan B.K., 2001. Effect of dietary absorbable methionine and lysine concentrations on milk production and composition of dairy cows offered grass-silage based dicts. Irish J. Agr. Food Res. 40, 1-11

\section{STRESZCZENIE}

Wplyw chronionej metioniny na wydajność i skład mleka krów żywionych niskobiałkową dawką pokarmową $\mathrm{z}$ udziałem kiszonki $\mathrm{z}$ traw

Doświadczenie przeprowadzono na 12 krowach wieloródkach rasy czerwono-bialej, w 8-12 tygodniu laktacji, w układzie dwuczynnikowym $(2 \times 2)$, zgodnie z założeniami zrównoważonego układu przemiennego. Zwierzçta żywiono dawkami pokarmowymi o zróżnicowanej podaży białka trawionego w jelicie cienkim (BTJ): 100 lub 85\% zapotrzebowania wg INRA, podawanymi bez dodatku lub $z$ dodatkiem chronionej syntetycznej DL-metioniny (Smartamine ${ }^{\mathrm{TM}} \mathrm{M}$ : 0 lub $20 \mathrm{~g} / \mathrm{d}$ ). Dawki pokarmowe zawierały (\% s.m.): kiszonkę z traw - 50 i mieszankę pasz treściwych - 50 . Każdą z czterech kombinacji czynników doświadczalnych (100\% BTJ $/ 0$ g Met, $100 \%$ BTJ $/+20$ g Met, $85 \%$ BTJ $/ 0$ g Met i $85 \%$ BTJ $/ 20 \mathrm{~g} \mathrm{Met)} \mathrm{badano} \mathrm{w} \mathrm{sześciu} \mathrm{powtórzeniach.} \mathrm{Obliczone} \mathrm{stężenia} \mathrm{jelitowe}$ lizyny $\mathrm{i}$ metioniny (\% BTJ) w dawkach doświadczalnych wynosiły odpowiednio: 6,91 i 1,$79 ; 6,88$ i 2,$27 ; 6,88$ i 1,$87 ; 6,84$ i 2,42 .

Nie stwierdzono istotnych różnic w pobraniu s.m. i encrgii netto (JPM), natomiast pobranie białka ogólnego $\mathrm{BTJ}(\mathrm{N})$ i $\mathrm{BTJ}(\mathrm{E})$ było istotnie $(\mathrm{P}<0,001)$ większe przez krowy żywione dawkami zapewniającymi podaż BTJ w $100 \%$, w porównaniu ze zwierzętami otrzymującymi dawki zawierające $85 \%$ BTJ. Wydajność mleka i efektywność jego produkcji nie różniły się. Zawartość tłuszczu, 
laktozy i suchej masy beztłuszczowej w mleku również była podobna. Podawanie dawek zapewniających podaż $100 \%$ BTJ zwiększało istotnie $(\mathrm{P}<0,05)$ wydajność białka mleka $(\mathrm{z} 0,67$ do $0,76 \mathrm{~kg} / \mathrm{d})$. Zawartość azotu niebiałkowego (NPN) i mocznika w mleku istotnie $(\mathrm{P}<0,001)$ się obniżyły, a względna zawartość białka w mleku (\% N ogólnego) istotnie $(\mathrm{P}<0,05)$ wzrosła, przy skarmianiu dawki o niższej zawartości białka ( $85 \%$ BTJ). Nie stwierdzono istotnego wpływu podawania Smartamine ${ }^{\mathrm{TM}}$ $\mathrm{M}$ ani też istotnych interakcji pomiędzy ilością białka w dawce (BTJ) i dodatkiem Smartamine ${ }^{\mathrm{TM}} \mathrm{M}$ na badane wskaźniki.

Stosowanie w żywieniu krów mlecznych dodatku chronionej metioniny do dawek pokarmowych opartych na kiszonce z traw i o zróżnicowanej zawartości białka (100 lub 85\% BTJ) nie miało wpływu na wydajność i skład mleka, co wskazuje, że metionina nie była pierwszym aminokwasem ograniczającym w warunkach przeprowadzonego doświadczenia. 